\section{MICROORGANISMS PROFILE AND ANTI-MICROBIAL SENSITIVITY IN CHRONIC SUPPURATIVE OTITIS MEDIA}

\section{Muhammad Ibrahim ${ }^{1 \otimes}$, Syed Maisam Ali', Muhammad Imran Shah', Muhammad Abkar Khan'}

\begin{abstract}
OBJECTIVE: To determine the frequency of common microorganisms involved in chronic suppurative otitis media (CSOM) and their antibiotic sensitivity.

METHODS: This cross sectional study of 776 patients suffering with CSOM was conducted at Otolaryngology Department, Ayub Teaching Hospital, Abbottabad from $5^{\text {th }}$ May 2017 to $5^{\text {th }}$ November 2018. Patients fulfilling the inclusion criteria were enrolled for otoscopic examination. Sterile cotton swabs were used to collect pus samples and were sent to microbiological analysis and antibiotics sensitivity.
\end{abstract}

RESULTS: The age ranges of the patients were from 13-73 years, with a mean age of $28.98 \pm 13.40$ years. The incidence of CSOM was highest in $21-30$ years age group (294 37.9\%). In a total 776 CSOM patients, only 50 I $(64.56 \%)$ of the samples showed microbial growth. In aerobic isolates, the most common bacterium was Pseudomonas aeruginosa (30.7\%) followed by Staphylococcus aureus (1I.1\%) including 6.7\% MRSA. Anaerobes were isolated in $1.2 \%$ of the samples in which bacteriodes were being the most common. Samples (I.8\%) showed fungal growth and yielded only Candida spp while $0.5 \%$ samples were positive for acid fact bacilli. In antimicrobial sensitivity investigation Pseudomonas aeruginosa showed highest sensitivity to piperacillin/tazobactum (84\%), to levofloxacin (25.21\%), to ciprofloxacin (20.59\%). The highest sensitivity of Staphylococcus aureus was investigated for piperacillin/tazobactum and ceftazidime with $91.18 \%$, and showed no sensitivity to ciprofloxacin and levofloxacin.

CONCLUSION: Pseudomonas aeruginosa and Staphylococcus aureus were the most common bacteria. Both show increasingly high resistance to quinolones and amino glycosides, but both isolates are sensitive to piperacillin/tazobactum, imipenam, cefoperazone/salbactum and ceftazidime.

KEY WORDS: Microorganisms (MeSH); Sensitivity (MeSH); Otitis Media, Suppurative (MeSH); Otitis Media (MeSH); Chronic suppurative otitis media (Non-MeSH); Antibiotics (MeSH); Pseudomonas (MeSH); Escherichia coli (MeSH); Staphylococcus (MeSH).

THIS ARTICLE MAY BE CITED AS: Ibrahim M, Ali SM, Shah MI, Khan MA. Microorganisms profile and anti-microbial sensitivity in chronic suppurative otitis media. Khyber Med Univ J 2019;II(4):248-52. DOI: 10.35845/kmuj.2019.18958

\section{INTRODUCTION}

C hronic suppurative otitis media (CSOM) is one of the commonest infectious disease of ear both in the developing and developed countries. ${ }^{1-3}$ The disease incidence is higher in the developing countries especially in those countries having poor socio-economic status because of unsatisfactory hygiene, nutritional deficiency, frequent upper respiratory tract infections, paucity of health education, under resourced health care, overcrowding, facial anomalies and
I. Department of ENT, Ayub Medical College, Abbottabad, Pakistan.

Email凶:dr_ibrahimorakzai@yahoo.com

Date Submitted:

January 25, 2019

Date Revised:

October 25, 2019

Date Accepted:

October 27, 2019

immunosupression. ${ }^{2-9}$ CSOM is a worldwide problem and individuals with all range of age are affected but particularly it is dominant in childhood. ${ }^{1-5,10,11}$ It affects approximately $2 \%$ of the overall population with urban: rural ratio of I:2..$^{1,8,10,12}$ Chronic suppurative otitis media is actually chronic inflammation and/or infection of the middle ear cleft (tympanic cavity, eustachian tube, aditus, antrum and mastoid air cells) having continuous or recurrent discharge of 3 months or more through a perforated tympanic membrane (TM) ${ }^{1.4,6-8,8,13-16}$ It is a disease of multiple etiology. ${ }^{17-19}$ The most common pathogenic factors in the disease are the bacterial infection and dysfunction of the eustachian tubes. ${ }^{16,20}$ The common symptoms of the disease are itching, ear discharge, deafness, pain and rarely fever. ${ }^{2}$ Depending upon the involvement of pars tensa or flaccida of the TM by the disease process, CSOM is divided into tubotympanic and atticoantral types respectively. ${ }^{6,9}$ Cholesteatoma may or may not be associated with CSOM. ${ }^{14}$ It causes a diversity of intracranial and extracranial complications because it is potentially a serious disease. ${ }^{2,15}$ The infection can extend beyond the confines of middle ear and can cause complications like deafness, paralysis of facial nerve, mastoid abscess, thrombophlebitis of the lateral sinus, labyrinthitis, petrositis intracranial abscess and meningitis. ${ }^{3,6,12,15}$ Hearing loss occurs in $50 \%$ cases of CSOM which is the most common complication. ${ }^{2}$ $6,12,17$ This may results into communication problems, hindering professional life and social interaction. ${ }^{12,21,22}$ The most common micro-organisms previously found in chronic suppurative otitis media include, Pseudomonas aeruginosa (45.9\%), Staphylococcus aureus (26.4\%), Proteus mirabilis (8\%), Klebsiella pneumoniae (2\%), Escherichia coli (6.8\%), Aspergillus sp and Candidasp (3.7\%). ${ }^{23}$

However the diversity and proportion of microorganisms existing in CSOM depend upon the geographical locations. Different geographical areas are having different profile of the microorganisms associated CSOM. ${ }^{5,23,24}$ Previous studies have reported different proportion of microorganisms 
TABLE I: LIST OF MICROORGANISMS TO BE CULTURED ${ }^{26-28}$

\begin{tabular}{|l|l|}
\hline \multicolumn{1}{|c|}{ Microorganisms } & \multicolumn{1}{c|}{ Identification } \\
\hline $\begin{array}{l}\text { Pseudomonas } \\
\text { aeruginosa }\end{array}$ & $\begin{array}{l}\text { Gram-ive rods, lactose non-fermenter, oxidase +ive, } \\
\text { producing blue green colonies on blood and chocolate agar. }\end{array}$ \\
\hline Staphylococcus aureus & $\begin{array}{l}\text { Gram +ive, clusters of cocci, catalase +ive, coagulase +ive, } \\
\text { producing golden yellow colonies on blood agar. }\end{array}$ \\
\hline Proteus mirabilis & $\begin{array}{l}\text { Gram -ive rods, lactose non-fermenter, oxidase -ive, } \\
\text { producing swarming growth on blood agar. }\end{array}$ \\
\hline Escherichia coli & $\begin{array}{l}\text { Gram -ive rods, lactose fermenter (fast), } \\
\text { producing pink purple dry colonies on MacConkey's agar }\end{array}$ \\
\hline Klebsiella pneumoniae & $\begin{array}{l}\text { Gram -ive rods, lactose fermenter (fast), producing } \\
\text { mucoid colonies on MacConkey's agar. }\end{array}$ \\
\hline Fungi & $\begin{array}{l}\text { Candida sp - white color 2-3mm colonies on Sabouraud's } \\
\text { agar. On microscopy, these are oval shaped \& } \\
\text { pseudohyphae are observed in germ tube test at 37*C. } \\
\text { Aspergilus sp-molds, not dimorphic producing green or } \\
\text { black colonies on Sabouraud's agar depending upon species } \\
\text { after 3 days at room temperature. }\end{array}$ \\
\hline
\end{tabular}

\section{TABLE II: LISTS OF ANTIBIOTICS TO BE CHECKED SENSITIVITY} AGAINST EACH CULTURE 26-28

\begin{tabular}{|l|c|c|c|c|}
\multirow{2}{*}{ Antibiotics } & \multicolumn{4}{|c|}{ Zone of inhibition-interpretive criteria nearest whole mm } \\
\cline { 2 - 5 } & Disk contents & Sensitive & Intermediate & Resistant \\
\hline Tazobactum/piperacillin & $100 / 10 \mu \mathrm{g}$ & $\geq 21$ & $15-20$ & $\leq 14$ \\
\hline Amoxicillin/clavulanic acid & $20 / 10 \mu \mathrm{g}$ & $\geq 18$ & $14-17$ & $\leq 13$ \\
\hline Ceftazidime & $30 \mu \mathrm{g}$ & $\geq 18$ & $15-17$ & $\leq 14$ \\
\hline Ceftriaxone & $30 \mu \mathrm{g}$ & $\geq 21$ & $14-20$ & $\leq 13$ \\
\hline Cefixime & $5 \mu \mathrm{g}$ & $\geq 19$ & $16-18$ & $\leq 15$ \\
\hline Ciprofloxacin & $5 \mu \mathrm{g}$ & $\geq 21$ & $16-20$ & $\leq 15$ \\
\hline Levofloxacin & $5 \mu \mathrm{g}$ & $\geq 17$ & $14-16$ & $\leq 13$ \\
\hline Gentamicin & $10 \mu \mathrm{g}$ & $\geq 15$ & $13-14$ & $\leq 12$ \\
\hline Amikacin & $30 \mu \mathrm{g}$ & $\geq 17$ & $15-16$ & $\leq 14$ \\
\hline Vancomycin & $30 \mu \mathrm{g}$ & $\geq 16$ & $14-16$ & $\leq 13$ \\
\hline Imipenam & $10 \mu \mathrm{g}$ & $\geq 19$ & $16-18$ & $\leq 15$ \\
\hline Cefoperazone/salbactum & $75 \mu \mathrm{g}$ & $\geq 21$ & $16-20$ & $\leq 15$ \\
\hline Chloramphenicol & $30 \mu \mathrm{g}$ & $\geq 18$ & $13-17$ & $\leq 12$ \\
\hline Clindamycin & $2 \mu \mathrm{g}$ & $\geq 21$ & $15-20$ & $\leq 14$ \\
\hline Tobramycin & $10 \mu \mathrm{g}$ & $\geq 15$ & $13-14$ & $\leq 12$ \\
\hline
\end{tabular}

like Shresta, et al. ${ }^{5}$ showed that the most common bacterial isolate is Staphylococcus aureus (32.2\%) followed by Pseudomonas aeruginosa $(26.9 \%)$ which is a contrast to so many other studies. This contradiction in studies might be due to difference of organisms in various geographical areas and the effect of climate. ${ }^{5}$

As the sensitivity pattern of the causative organisms CSOM is changing rapidly in our region where over the counter use of antibiotics is very common, we planned this study to find out the most common microorganisms involved and their antibiotic sensitivity in patients with CSOM in our region.

\section{METHODS}

This cross sectional study comprises of 776 CSOM patients with consecutive nonprobability sampling was conducted at outdoor patient department of ENT, head and neck surgery of Ayub Teaching Hospital, Abbottabad from $5^{\text {th }}$ May 2017 to $5^{\text {th }}$ November 2018. Both, male and female patients with age of above 12 years, having active ear discharge, ear discharge of more than 3 months, unilateral or bilateral ear discharge, were included in this study, while patients having ear discharge with aural polyp, external auditory canal pathology or any existing ear malignancy, having had mastoid surgery in the preceding 12 months and those who had used antibiotics in the last 7-10 days were excluded from study. Informed consent was taken from all patients. The biodata of the patients along with hospital registration number were entered on proforma. The patients were assessed initially by history and otoscopic examination. Pus samples collected on sterile swabs for culturing of microorganisms from the discharging ear(s) were sent to consultant microbiologist in the hospital's pathology laboratory for processing. Lab reports of the pus swab collected from the discharging ear showing the bacterial spectrum and their sensitivity to antibiotics were reviewed and data entered in the proforma.

For aerobes, samples were inoculated onto chocolate agar and blood agar whereas medium of Robertson's cooked meat and neomycin blood agar were used for anaerobes. Sabouraud's dextrose agar was used for fungal culture. The bacterial isolates were identified using gram staining, colony morphology, coagulase, catalase \& oxidase tests while fungal species were identified by India ink preparation \& microscopy, and colony morphology. ${ }^{25-27}$ The details of each aerobic bacteria and fungi is given in the Table I. In case of anaerobic bacterial culture processing, before inoculation Robertson's cooked meat medium (pieces of fat free minced cooked meat of ox heart) is boiled to make it oxygen free (by reducing agents present in meat like unsaturated fatty acids, glutathione \& cysteine). Neomycin is added to medium to selectively inhibit the growth of gram-negative microorganisms. After inoculation the medium is covered with a layer of sterile liquid paraffin oil to prevent entry of oxygen to medium.

Mueller Hinton agar was used for testing of antibiotic sensitivity by modified method of Kirby-Bauer disc diffusion, in which different types of antibiotics saturated on small disks of filter paper, were placed onto the bacterial lawn. After incubation period of 18-24 hours, the plate was examined to see the bacterial growth whether it was inhibited (or not) by measuring clear zone of no bacterial growth around the antibiotic disk. ${ }^{25-27}$

All the data was entered in SPSS version 19.0 and analyzed. To calculate frequencies, percentages, means and standard deviation for both qualitative and quantitative variables, descriptive statistics were applied. The qualitative variables or categorical data like culture \& sensitivity findings were expressed as frequency and 
TABLE III: PERCENTAGE OF DIFFERENT MICROORGANISMS ISOLATED FROM CSOM $(n=776)$

\begin{tabular}{|l|l|c|}
\hline \multicolumn{2}{|l|}{ Microorganisms isolated } & Percentage \\
\hline \multirow{4}{*}{$\begin{array}{l}\text { Positive growth } \\
(n=50 I)\end{array}$} & Monomicrobial growth & $58.1 \mathrm{I}$ \\
\cline { 2 - 3 } & Polymicrobial growth & 6.4 \\
\cline { 2 - 3 } & Aerobes & 54.8 \\
\cline { 2 - 3 } & Pseudomonas aeruginosa & 30.7 \\
\cline { 2 - 3 } & Staphylococcus aureus & $\mathrm{II} . \mathrm{I}$ \\
\cline { 2 - 3 } & Escherichia coli & 5.7 \\
\cline { 2 - 3 } & Proteus spp & 3.9 \\
\cline { 2 - 3 } & Klebsiella pneumoniae & 3.4 \\
\cline { 2 - 3 } & Anaerobes & 1.2 \\
\cline { 2 - 3 } & Bacteriodes & 0.8 \\
\cline { 2 - 3 } & Peptostreptococcus & 0.3 \\
\cline { 2 - 3 } & Prevotenellamelaninogenica & 0.1 \\
\cline { 2 - 3 } & Fungi (Candida spp) & 1.8 \\
\cline { 2 - 3 } & Acid fast bacilli (AFB) & 0.5 \\
\hline No growth $(\mathrm{n}=275)$ & & 35.44 \\
\hline
\end{tabular}

TABLE IV: PERCENTAGE OF SENSITIVITY OF DIFFERENT BACTERIA ISLOLATED FROM CSOM TO DIFFERENT ANTIBIOTICS $(n=50$ I)

\begin{tabular}{|l|c|c|c|c|c|c|}
\hline \multirow{2}{*}{ Antibiotic } & \multicolumn{6}{|c|}{ Bacteria Isolated (Percentage) } \\
\cline { 2 - 7 } & P. aeruginosa & S. aureus & MRSA & E coli & Proteus spp & K. Pneumoniae \\
\hline $\begin{array}{l}\text { Piperacillin/ } \\
\text { Tazobactum }\end{array}$ & 84 & 91.18 & -- & 100 & 100 & 100 \\
\hline Imipenam & 65.13 & -- & -- & 97.73 & -- & 80.77 \\
\hline $\begin{array}{l}\text { Cefoperazone/ } \\
\text { Salbactum }\end{array}$ & 61.34 & 67.65 & -- & -- & 93.33 & -- \\
\hline Amikacin & 59.24 & -- & -- & 18.18 & -- & 69.23 \\
\hline Ceftazidime & 58.4 & 91.18 & 0 & 38.64 & 86.67 & 38.46 \\
\hline Tobramycin & 44.12 & -- & -- & -- & 63.33 & 53.85 \\
\hline Levofloxacin & 25.21 & 0 & 0 & 47.73 & 100 & -- \\
\hline Ciprofloxacin & 20.59 & 0 & 28.85 & -- & 36.67 & -- \\
\hline Ceftriaxone & 11.76 & 55.88 & 0 & -- & 70 & 34.62 \\
\hline $\begin{array}{l}\text { Amoxicillin/ } \\
\text { Clavulanic acid }\end{array}$ & -- & 64.71 & -- & -- & -- & -- \\
\hline Vancomycin & -- & -- & 84.62 & -- & -- & - \\
\hline Chloramphenicol & & -- & 73.08 & -- & -- & -- \\
\hline
\end{tabular}

percentages while quantitative variables or numerical data such as age were expressed as mean \pm standard deviation.

\section{RESULTS}

After processing of total 776 ear swabs, only 50 I $(64.56 \%)$ samples showed microbial growth while 275 (35.4\%) samples yielded no growth. Monomicrobial growth was seen in $45 \mathrm{I}$ (58.11\%) samples whereas 50 (6.4\%) samples showed poly-microbial growth. Anaerobes were isolated in $6(1.2 \%)$ of the samples. Only 9 (I.8\%) samples showed fungal growth and $2(0.5 \%)$ samples were positive for AFB.
The age ranges of the patients were from 13 to 73 years, with a mean age of $28.98 \pm 13.40$ years. The incidence of CSOM was highest in 21-30 years age group $(294 \sim 37.9 \%)$ followed by age group of $12-20$ years 247 (31.8\%). Least common age group was $50+$ years 59 (7.6\%). In this study, the percentage of male patients was 426 (54.9\%) while female' percentage was 350 (45.1\%) with a male to female ratio of $1.21: 1$. The duration of ear discharge was 3-12 months in $345(44.5 \%)$ patients, 13-24months in $210(27.1 \%)$ patients, $25-36$ months in 82 (10.6\%) patients and $36+$ months in 139 (17.9\%) patients. Most of the patients were having continuous ear discharge 45 I
(58.1\%) followed by intermittent ear discharge 203 (26.2\%) and then recurrent ear discharge 122 (15.7\%). The most common TM perforation was central in $653(84.1 \%)$ ears followed by subtotal 50 $(6.4 \%)$, then total $37(4.8 \%)$, attic 21 $(2.7 \%)$ and the least common perforation was marginal in $15(1.9 \%)$ ears.

The details of positive sample as per organism based are shown in Table III. The sensitivity of different drugs with respect organisms is highlighted in detail as per Table IV.

\section{DISCUSSION}

CSOM is a genuine healthcare issue around the world, not only because of the disease for patient and their family but it also puts significant financial burden on healthcare system. In this study 2I-30 years of age group was having the highest incidence of CSOM (37.9\%) followed by age group of 12-20 years $(31.8 \%)$ which is consistent with the results of Kumar $\mathrm{H}$, et al., ${ }^{8}$ Iqbal K, et al. ${ }^{23}$ and Mansoor T, et al. ${ }^{24}$ in contrast to Prakash R, et al., ${ }^{6}$ Jayanthi SR, et al. ${ }^{7}$ and Arvind $\mathrm{N}$, et al. ${ }^{15}$ who reported that CSOM is more common in the age group of below 20 years. CSOM is more common in male with a male to female ratio of $1.21: 1$ which is consistent with most of the studies $^{1,3,8,14,16,23}$ but Meyer E, et al., Prakash $\mathrm{R}$, et al., Jayanthi SR, et al. and Mansoor T, et al. reported that CSOM is more common in female as compared to male. ${ }^{6,7,13,24}$ The males having more exposed pattern of life may have been results in their predominance. ${ }^{8}$ Most of the studies showed monomicrobial isolates to be more common as compared to polymicrobial isolates , $7,16,24$ which is consistent with our study. Central perforation of TM was more common (84.1\%) and most of the studies also showed that central perforation was more common $^{5,23}$ but Nikakhlagh S, et al..$^{14}$ said that marginal perforation of TM associated with CSOM was more common which is in contradiction to our study.

This study showed that Pseudomonas aeruginosa and $\mathrm{S}$. aureus were the major isolates involved in CSOM. The sensitivity pattern of these organisms showed that they were more sensitive to piperacillin/tazobactum, imipenam, cefoperazone/salbactumbut increasingly becoming more resistant to quinolones and aminoglycosides.

Among aerobic isolates, the most common was Pseudomonas aeruginosa (30.7\%) followed by S. aureus (II.I\%) (including 
6.7\% MRSA) which is consistent with most of the national and international studies ${ }^{2 .}$ $5,15,23,24$ but studies from India, Iran and South Africa showed that $S$. aureus was the most frequent bacterium in CSOM as compare to Pseudomonas aeruginosa. ${ }^{6,13,14,16,28}$ While other 2 researches carried out in Nigeria and India showed that the commonest isolate was Pseudomonas followed by Klebsiella. ${ }^{1,7}$

In this study Pseudomonas aeruginosa showed highest sensitivity to piperacillin/tazobactum (84\%) followed by i m ipenam (65.13\%) then cefoperazone/salbactum (6I.34\%), amikacin (59.24\%), ceftazidime (58.40\%), tobramycin (44.12\%). The sensitivity to levofloxacin was $25.21 \%$, ciprofloxacin $20.59 \%$ and ceftriaxone $1 \mathrm{I} .76 \%$. In recent past Pseudomonas aeruginosa has showed decreasing pattern in sensitivity to quinolones worldwide. ${ }^{29}$

In Turkey a study was conducted in 1996 in which only $6 \%$ Pseudomonas aeruginosa isolates were resistance to ciprofloxacin ${ }^{30}$ while in another study conducted in South Korea in $2004,100 \%$ of the isolates showed resistance to ciprofloxacin. ${ }^{31}$ The studies conducted in different areas of Pakistan showed more than $80 \%$ sensitivity. ${ }^{4,23,24}$ In contrast, our study showed less than $26 \%$ sensitivity to quinolones. The deteriorating sensitivity pattern may be due to a variety of factors like imprudent antibiotic use, inadequate dosage, developing enzymatic resistance of organism towards quinolones and easy availability, ${ }^{4}$ same increasing resistances of aminoglycosides have also been noted against $P$ seudomonas aeruginosa.

The highest sensitivity of $\mathrm{S}$. aureus (other $\mathrm{t} h$ a $\mathrm{n}$ M R A ) w a s to piperacillin/tazobactum and ceftazidime ( 9 I . I $8 \%$ ) follow ed by cefoperazone/salbactum $(67.65 \%)$, amoxicillin/clavulanate (64.7I\%), ceftriaxone $(55.88 \%)$ and $0 \%$ sensitive to ciprofloxacin and levofloxacin. The sensitivity pattern of amoxicillin/clavulanate against $S$. aureus in our study is in accordance with other studies, ${ }^{2,16,28}$ but the sensitivity pattern of $S$. aureus shows a downward trend to quinolones for the last few years. A study conducted in Iran in 201 I showed $85.4 \%$ sensitivity of $S$. aureus to ciprofloxacin, ${ }^{28}$ whereas in Karachi, Pakistan a study conducted in 2013 showed $60 \%$ sensitivity to ciprofloxacin ${ }^{2}$ and other study carried out in India in 2014 showed $55.3 \%$ sensitivity to ciprofloxacin ${ }^{16}$ while in our study S. aureus showed $0 \%$ sensitivity to ciprofloxacin.

\section{CONCLUSION}

The most microorganisms Pseudomonas aeruginosa and Staphylococcus aureus are increasingly becoming more resistant to quinolones and aminoglycosides, but in our study both isolates were more sensitive to piperacillin/tazobactum, imipenam, cefoperazone/salbactum and ceftazidime.

\section{REFERENCES}

I. Afolabi OA, Salaudeen AG, Ologe FE, Nwabuisi C, Nwawolo CC. Pattern of bacterial isolates in the middle ear discharge of patients with chronic suppurative otitis media in a tertiary hospital in north central Nigeria. Afr Health Sci 20I2; I2(3):362-7. DOI: 10.43|4/ahs.v|2i3.18.

2. Fatima G, Shoaib M, Raza MZ, Bilal S. Antimicrobial susceptibility pattern of bacterial and fungal isolates from patients with chronic suppurative otitis media in perspective of emerging resistance. Pak J Otolaryngol 2013;29(2):49-53.

3. Adoga A, Nimkur T, Silas O. Chronic suppurative otitis media: Socioeconomic implications in a tertiary hospital in northern Nigeria. Pan Afr Med J 20I0:4:3. DOI: DOI: I0.43 I4/pamj.v4il.536I3.

4. Mirza IA, Ali L, Ali L, Arshad M. Microbiology of chronic suppurative otitis media-Experience at Bahawalpur. Pak Armed Forces Med J 2008;58(4):372-6.

5. Kumar J, Hima BP. Clinical and bacteriological study of chronic suppurative otitis media by anaerobic culture methods in a teaching hospital. Napalese J ENT Head Neck Surg 20|2;3(2):|2-4. DOI: $|0.3| 26 \mid$ njenthns.v3i2.10I55.

6. Prakash $R$, Juyal $D$, Negi $V$, Pal $S$, Adekhandi S, Sharma $M$, et al. Microbiology of chronic suppurative otitis media in a tertiary care setup of Uttarakhand state, India. N Am J Med Sci $2013 ; 5(4): 282-7$. DOI: |0.4I03/|947-27|4.| I0436.

7. Jayanthi SR, Venkatesh R, Jeya M. Study of aerobic bacterial and fungal etiology of chronic suppurative otitis media in tertiary care hospital in out skirts of Chennai, India. Int J Res Health Sci 2013; I (3): 199-203.

8. Kumar $\mathrm{H}$, Seth $\mathrm{S}$. Bacterial and fungal study of 100 cases of chronic suppurative otitis media. J Clin Diagn Res 20 I I;5(6 Suppl I):SI 224-7.

9. Hiremath SL, Kanta RC, Yeshwanathrao M, Vasantha Kumar CM. Aerobic bacterial isolates of CSOM and their antibiotic sensitivity pattern. Indian Pract 200I;54(7):4869.

10. Park MK, Nam DW, Byun JY, Hong SM, Bae $\mathrm{CH}$, Lee HY et al. Differences in antibiotic resistance of MRSA infection in patients with various types of otitis media. J Int Adv Otol 2018; 14(3):45965. DOI: I0.5 I52/iao.2018.5374.

I I. Mokrzan EM, Novotny LA, Brockman $\mathrm{KL}$, Bakaletz LO. Antibodies against the majority subunit (PilA) of the Type IV Pilus of Non typeable Haemophilus influenza Disperse Moraxella catarrhalis from a Dual-Species Biofilm. MBio 2018;9(6):e02423-18. DOI: I0.I I 28/mBio.02423- I8.

12. Baumann I, Gerendas B, Plinkert PK, Praetorius M. General and diseasespecific quality of life in patients with chronic suppurative otitis media-a prospective study. Health Qual Life Outcomes 2011;9(I):48. DOI: 10.1 I86/1477-7525-9-48.

13. Meyer E, Whitelaw A, Edkins O, Fagan JJ. Chronic otorrhea: Spectrum of Microorganisms and antibiotic sensitivity in a South African cohort. S Afr Med J 2013;103(7):47I-3. DOI: 10.7196/samj.6066.

14. Nikakhlagh S, Khosravi AD, Fazlipour A, Safarzadeh M, Rashidi N. Microbiologic findings in patients with chronic suppurative otitis media. J Med Sci 2008;8(5):503-6. DOI: 10.3923/jms.2008.503.506.

15. Arvind N, Chand P, Vishrutha KV. Microbiological profile of chronic suppurative otitis media. Int J Biomed R 20I4;5(3):204-6. DOI: 10.7439/ijbr.v5i3.560.

16. Agrawal A, Kumar D, Goyal A, Goyal S, Singh N, Khandelwal G. Microbiological profile and their antimicrobial sensitivity pattern in patients of otitis media with ear discharge. Indian J Otol 2013;19(I):58. DOI: I0.4I03/097I-7749. I08I49.

17. Rao MV, Jayakar PA. Bacteriological study of chronic suppurative otitis media. J Indian Med Assoc 1980;75(2):30-4.

18. Coleman A, Wood A, Bialasiewicz S, 
Ware RS, Marsh RL, Cervin A. the unsolved problem of otitis media in indigenous populations: a systemic review of upper respiratory and middle ear microbiology in indigenous children with otitis media. Microbiome 2018;6(I):199. DOI: 10.1186/s40168018-0577-2.

19. Arikan TA, Kelles M. Plasma selenium and cadmium levels in patients with chronic otitis media in a Turkish population and their relation to inflammation markers. Biol Trace Elem Res 2019;189(I): 55-63. DOI: |0.1007/s |201|-0|8-1520-x.

20. Lee SK, Park DC, Kim MG, Boo SH, Choi YJ, Byun JY, et al. Rate of isolation and trends of antimicrobial resistance of multidrug resistant pseudomonas aeruginosa from otorrhea in chronic suppurative otitis media. Clin Exp Otorhinolaryngol 20I2;5(I): 17-22. DOI: I0.3342/ceo.2012.5.1.17.

21. Goyal N, KakkarV, Goyal P, Yadav SPS. Myringoplasty for chronic otitis media. Indian J Pediatr 2002;69(2): 223-4. DOI: 10.1007/BF02734225.

22. Rak K, Völker J, Schendzielorz P, Kaulitz S, Steinbach J, Shehata-Dieler $W$, et al. Cochlear implantation in chronic otitis media: Investigation of long term speech comprehension and rate of complications. Otol Neurotol
20I8;39(I0):e979-e984. DOI: 10. 1097/MAO.00000000000002026

23. Iqbal K, Khan MI, Satti L. Microbiology of chronic suppurative otitis media: Experience at Dera Ismail Khan. Gomal J Med Sci 20 I I;9(2): I89-93.

24. Mansoor T, Musani MA, Khalid G, Kamal M. Pseudomonas Aeruginosa in chronic suppurative otitis media: Sensitivity spectrum against various antibiotics in Karachi. J Ayub Med Coll Abbottabad 2009;2 I (2): I 20-3.

25. Baron JE, Peterson LR, Finegold SM. Bailey and Scott's Diagnostic Microbiology. $13^{\text {th }}$ ed. United States of America: Mosby-Year Book Inc; 1994. [Cited on: December 12, 2018]. Available from URL: https://www. elsevier.com/books/bailey-and-scottsdiagnostic-microbiology/tille/978-0323-08330-0.

26. Vandepitte J, Verhaegen J, Engbaek K, Rohner P, Piot P, Heuck CC. Basic laboratory procedures in clinical bacteriology. $2^{\text {nd }}$ edition. Geneva, Swizerland: World Health Organisation (WHO); 2003. [Cited on: December 12, 2018]. Available from URL: https://apps.who.int/ medicinedocs/documents/s I6536e/s I 6536e.pdf.

27. llechukwu GC, llechukwu AC, Ubesie AC, Okoroafor I, Ezeanolue BC,
Ojinnaka NC. Bacterial agents of the discharging middle ear among children seen at the Umiversity of Nigeria Teaching Hospital, Enugu. Pan Afr Med J 2017;26:87. DOI:10.II604/pamj. 2017.26.87.9243.

28. Nia KM, Sepehri G, Khatmi H, Shakibaie MR. Isolation \& antimicrobial susceptibility of bacteria from chronic suppurative otitis media patients in Kerman, Iran. Iran Red Crescent Med J 20II;I3(I2):89|-4.

29. Gorems K, Beyene G, Berhane M, Mekonnen Z. Antimicrobial susceptibility patterns of bacteria isolated from patients with ear discharge in Jimma Town, Southwest, Ethiopia. BMC Ear Nose Throat Disord $20|8 ;| 8: \mid 7$. DOI: |0.||86/s|290|-0|8-0065-0.

30. Altuntas A, Aslam A, Eren A, Unal A, Nalca Y. Susceptibility of microorganisms isolated from chronic suppurative otitis media to ciprofloxacin. Eur Arch Otorhinolaryngol 1996;253(6):364-6. DOI: 10.1007/bf00 I 78293 .

31. Jang $\mathrm{CH}$, Park SY. Emergence of ciprofloxacin resistant pseudomonas in chronic suppurative otitis media. Clin Otolaryngol 2004;29(4):32I-3. DOI: $10.1 \mathrm{II} / \mathrm{j} .1365-2273.2004$ 00835.x.

\section{AUTHORS' CONTRIBUTIONS}

Following authors have made substantial contributions to the manuscript as under:

MI: Conception and study design, drafting the manuscript, critical review, final approval of the version to be published

SMA, MIS \& MAK: Acquisition, analysis and interpretation of data, drafting the manuscript, final approval of the version to be published

Authors agree to be accountable for all aspects of the work in ensuring that questions related to the accuracy or integrity ofany part of the work are appropriately investigated and resolved.

\begin{tabular}{|c|}
\hline CONFLICT OF INTEREST \\
Authors declared no conflict of interest \\
GRANT SUPPORT AND FINANCIAL DISCLOSURE \\
NIL
\end{tabular}

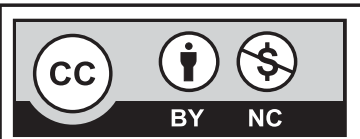

This is an Open Access article distributed under the terms of the Creative Commons Attribution-Non Commercial 2.0 Generic License. 